\title{
,anu \\ Methane Mitigation Potential of Foliage of Fodder Trees Mixed at Two Levels with a Tropical Grass
}

\author{
Sara Stephanie Valencia-Salazar ${ }^{1,2}, * \mathbb{0}$, Guillermo Jiménez-Ferrer ${ }^{1}\left(\mathbb{D}\right.$, Isabel Cristina Molina-Botero ${ }^{3}$, \\ Juan Carlos Ku-Vera ${ }^{4}$, Ngonidzashe Chirinda ${ }^{2,5}$ and Jacobo Arango ${ }^{2}$
}

1 The College of the Southern Border (ECOSUR), Livestock and Environment, Carrera Panamericana-Periferico sur, P.C., San Cristobal de las Casas 29290, Mexico; gjimenez@ecosur.mx

2 International Center for Tropical Agriculture (CIAT), km 17, Recta Cali-Palmira, Palmira, Valle del Cauca, Cali, P.C., Cali 763537, Colombia; nchirinda@gmail.com (N.C.); j.arango@cgiar.org (J.A.)

3 Department of Nutrition, Faculty of Animal Science, Universidad Agraria La Molina, La Molina, P.C., Lima 12456, Peru; hyzavell26@gmail.com

4 Faculty of Veterinary Medicine and Animal Science, University of Yucatan, Carretera Merida-Xmatkuil km 15.5, Apdo. 4-116 Itzimná, P.C., Merida 97100, Mexico; kvera@correo.uady.mx

5 AgroBioSciences (AgBS), Agricultural Innovations and Technology Transfer Centre (AITTC), Mohammed VI Polytechnic University, Benguerir, P.C., Ben Guerir 43150, Morocco

* Correspondence: saraudea@gmail.com; Tel.: +57-323-2312470

check for

updates

Citation: Valencia-Salazar, S.S.;

Jiménez-Ferrer, G.; Molina-Botero, I.C.; Ku-Vera, J.C.; Chirinda, N.; Arango, J. Methane Mitigation Potential of

Foliage of Fodder Trees Mixed at Two Levels with a Tropical Grass.

Agronomy 2022, 12, 100. https://

doi.org/10.3390/agronomy12010100

Academic Editors: M. Jordana Rivero and Mary Bridget Lynch

Received: 22 November 2021

Accepted: 29 December 2021

Published: 31 December 2021

Publisher's Note: MDPI stays neutral with regard to jurisdictional claims in published maps and institutional affiliations.

Copyright: (C) 2021 by the authors. Licensee MDPI, Basel, Switzerland. This article is an open access article distributed under the terms and conditions of the Creative Commons Attribution (CC BY) license (https:// creativecommons.org/licenses/by/ $4.0 /)$.

\begin{abstract}
Enteric methane $\left(\mathrm{CH}_{4}\right)$ emitted by ruminant species is known as one of the main greenhouse gases produced by the agricultural sector. The objective of this study was to assess the potential the potential for $\mathrm{CH}_{4}$ mitigation and additionally the chemical composition, in vitro gas production, dry matter degradation (DMD), digestibility and $\mathrm{CO}_{2}$ production of five tropical tree species with novel forage potential including: Spondias mombin, Acacia pennatula, Parmentiera aculeata, Brosimum alicastrum and Bursera simaruba mixed at two levels of inclusion (15 and 30\%) with a tropical grass (Pennisetum purpureum). The forage samples were incubated for $48 \mathrm{~h}$, and a randomized complete block design was used. Crude protein content was similar across treatments (135 $\left.\pm 42 \mathrm{~g} \mathrm{~kg}^{-1} \mathrm{DM}\right)$, while P. purpureum was characterized by a high content of acid detergent fiber $\left(335.9 \mathrm{~g} \mathrm{~kg}^{-1} \mathrm{DM}\right)$ and B. simaruba by a high concentration of condensed tannins $\left(20 \mathrm{~g} \mathrm{~kg}^{-1} \mathrm{DM}\right)$. Likewise, A. pennatula and P. aculeata were characterized by a high content of cyanogenic glycosides and alkaloids respectively. Treatments SM30-PP70 (30\% S. mombin + 70\% P. purpureum) and BA30-PP70 (30\% B. alicastrum $+70 \%$ P. purpureum) resulted in superior degradability at $48 \mathrm{~h}$ than P. purpureum, while in the AP30-PP70 $(30 \%$ A. pennatula $+70 \%$ P. purpureum) was lower than the control treatment $(p \leq 0.05)$. At 24 and $48 \mathrm{~h}$, treatments that contained P. aculeata and B. alicastrum yield higher $\mathrm{CH}_{4} \mathrm{~mL} \mathrm{~g}^{-1} \mathrm{DOM}$ than P. purpureum $(p \leq 0.05)$. The inclusion of these forage species had no statistical effect on the reduction of $\mathrm{CH}_{4}$ emissions per unit of DM incubated or degraded at 24 and $48 \mathrm{~h}$ with respect to P. purpureum although reductions were observed. The use of fodders locally available is an economic and viable strategy for the mitigation of the environmental impact generated from tropical livestock systems.
\end{abstract}

Keywords: in vitro; greenhouse gases; ruminal degradation; secondary metabolites; tropical livestock systems

\section{Introduction}

Methanogenesis in the gastrointestinal tract of ruminant species is the main sink for hydrogen, thus assuring the appropriate fermentation of fiber in the rumen [1]. Due to $\mathrm{CH}_{4}$ synthesis, ruminants can make use of high-fiber diets (not edible for humans) growing abundantly on enormous land areas, marginal to crop agriculture and convert it into high quality food (e.g., milk, meat) for humans as well as other products derived from livestock [2]. Eructated $\mathrm{CH}_{4}$ is part of natural cycles and can be transformed by methanotrophic bacteria and reactions with hydroxyl radicals $(\mathrm{OH})$ in the air, to carbon 
dioxide $\left(\mathrm{CO}_{2}\right)$ that will be used in photosynthesis [3]. However, high emission rates of $\mathrm{CH}_{4}$ in cattle constitute an energy loss and production inefficiency, especially in tropical production systems where poorly managed grasses are used as feed [4,5]. Additionally, due to methane's global warming potential (GWP) and its contribution to greenhouse gas (GHG) emissions in the agricultural sector, it has gained attention in the last 20 years for research on mitigation alternatives in livestock production [1]. Some of these alternatives are focused on interfering with $\mathrm{CH}_{4}$ synthesis in the rumen.

In the rumen there is a whole consortium of microorganisms that establish syntrophic relationships between them and of mutualism with their host [6]. The diversity and structure of microbial populations in the rumen will depend on the characteristics of the feed consumed by the ruminant [7]. These microbial populations use the compounds in ruminant diets for their growth and produce volatile fatty acids (VFA), metabolic hydrogen $\left(\mathrm{H}_{2}\right)$ and $\mathrm{CO}_{2}$ as by-products [8]. Rumen bacteria are the most abundant and diverse group of microorganisms in the rumen ecosystem and carry out enzymatic activities for the fermentation of starch, cellulose, hemicellulose, proteins, and lipids [9]. Protozoa comprise a large proportion (approximately 20\%) of the microbial mass of the rumen due to their size and can be up to $50 \%$ in some cases depending on the diet [9]. They can degrade fiber and have been directly related to the synthesis of $\mathrm{CH}_{4}$ due to their hydrogensomes that produce $\mathrm{H}_{2}$ that serves as a substrate for methanogenic archaea [10]. Archaea are chemolythophic organisms that use acetate, methyl groups, $\mathrm{CO}_{2}$ and $\mathrm{H}_{2}$ as a substrate for the synthesis of $\mathrm{CH}_{4}$ [6]. Methanogenic archaea of the rumen produce $\mathrm{CH}_{4}$ mainly through the hydrogenotrophic pathway and to a lesser extent through the methylotrophic and acetoclastic pathways [11]. These biochemical pathways have in common the presence of methyl-coenzyme $\mathrm{M}$ reductase (Mcr), responsible for the last step in the reduction of the methyl group to $\mathrm{CH}_{4}$ [12]. Each of the steps of hydrogenotrophic methanogenesis are shown in Figure 1.

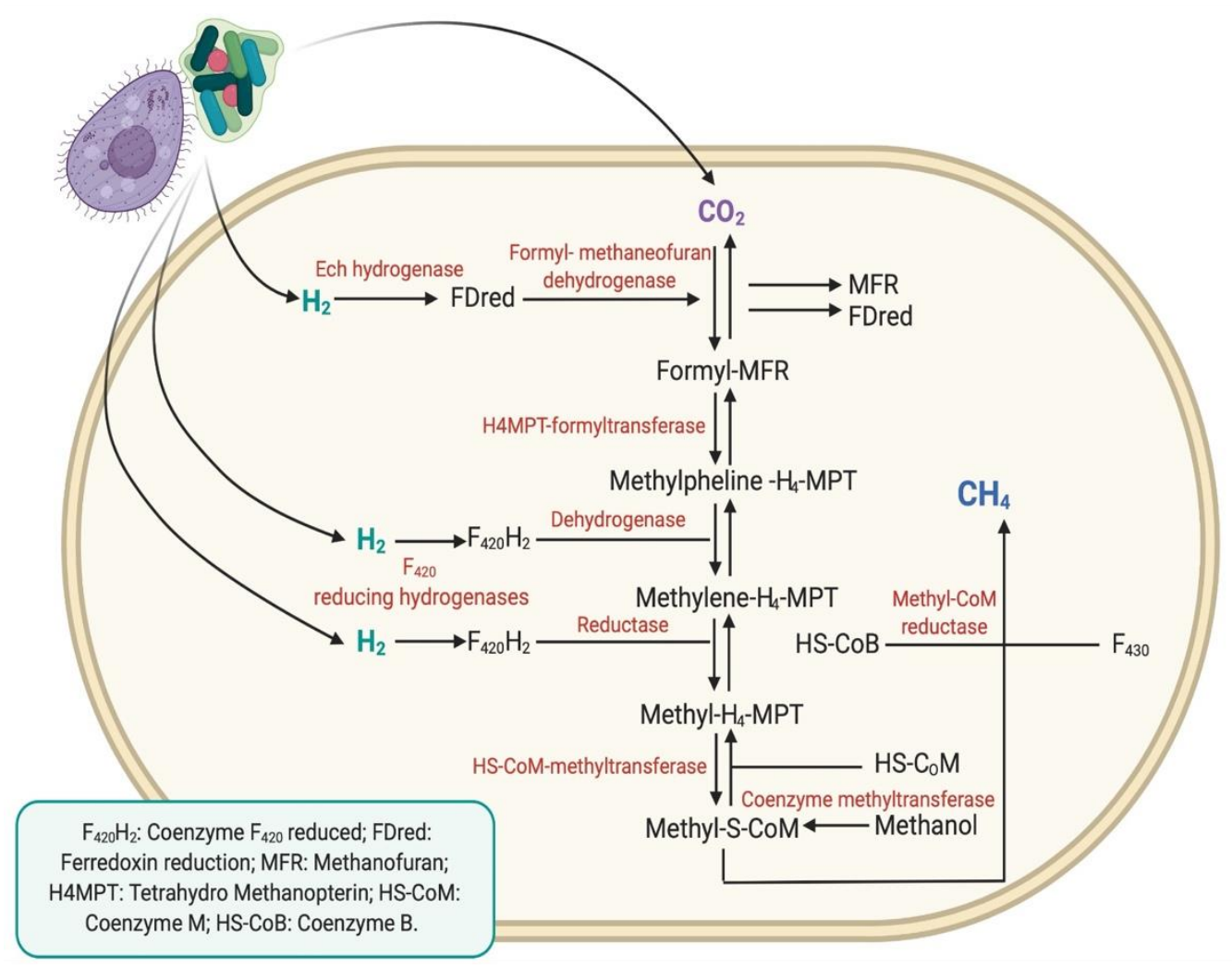

Figure 1. Hydrogenotrophic methanogenesis. Abbreviations: $\mathrm{CH}_{4}$ : methane, $\mathrm{CO}_{2}$ : carbon dioxide, $\mathrm{H}_{2}$ : dihydrogen. 
Nutritional strategies for the reduction of enteric $\mathrm{CH}_{4}$ production in ruminants have been widely studied [13]. Some of these strategies that have shown medium to high $\mathrm{CH}_{4}$ mitigation potential include concentrates, lipids, algae, nitrates, and chemical inhibitors such as 3-nitrooxypropanol [1]. However, commercial $\mathrm{CH}_{4}$ mitigation sources in tropical regions can represent a high cost for medium and small producers and be difficult to implement in extensive grazing systems $[1,14]$. However, biomass diversity in the tropics can offer a vast diversity of low-cost alternatives for $\mathrm{CH}_{4}$ reduction and the improvement of cattle production to more sustainable systems. Many native tree and shrub species have a high forage potential due to their nutritional quality and secondary metabolite content that have shown to be beneficial to ruminant metabolism [15]. These metabolites from plants have the capacity to modulate the rumen microbiome and reduce $\mathrm{CH}_{4}$ synthesis [16]. In addition, the use of forestry species due to their role in biogeochemical cycles can benefit the whole production system when used in combination with well managed forage-grass species [17]. Therefore, livestock production systems have a great GHG mitigation potential within the agricultural sector due to its close relation to natural biological cycles and its capacity of transformation to efficient and sustainable systems.

Livestock production in Latin America and the Caribbean is based on extensive systems that for years have promoted the deforestation of large forest areas for the sowing of pastures. Under these conditions, most of the dry matter consumed by cattle comes from medium to low quality pastures [18] and the dry seasons contribute to a scarce supply of forage and a decrease in consumption causing the animals to only cover their maintenance requirements. In this sense, five novel tropical tree species with forage potential evaluated in this study were collected at the Lacandon rainforest, one of the most important ecosystems in Mexico, however one of the main economic activities is extensive cattle production that has generated significant deforestation in the region [19]. By using the Global Forest Watch Pro platform (https: / /www.globalforestwatch.org (accessed on: 15 July 2020)), the loss of tree cover was monitored between 2011 to 2019. A loss of 145,000 ha was recorded, equivalent to a $12 \%$ decrease in tree cover since the year 2000 , registering the greatest loss in 2019. Many Mayan indigenous and "mestizo" livestock producers use secondary vegetation in critical periods of the year to improve cattle diets due to the low nutritional quality of the pasture in those periods. However, most of the land used for cattle production is directed towards extensive grazing as most of the livestock systems in tropical regions.

Additionally, there is not much knowledge on the biodiversity that exists at the regional level that can be used for cattle production and information on the use of native resources for the design of pastoral systems and management of these species is needed. Introduced species and silvopastoral systems have been promoted and the use of native species has been minimized despite its potential for small and medium producers in tropical countries to improve the cattle's diets and its capacity to regenerate soils and deforested regions. In this respect, the objective of this study was to quantify in vitro $\mathrm{CH}_{4}$ mitigation potential, nutritional quality, and digestibility of ten experimental diets composed of S. mombin, A. pennatula, P. aculeata, B. alicastrum and B. simaruba replacing 15 and $30 \%$ (of DM) of grass-based rations designed to be fed to tropical cattle.

\section{Materials and Methods}

\subsection{Description of the Study Area}

Forage species were sampled in the Ocosingo Valley of the Lacandon Rainforest, in the East and Northeast of Chiapas, Mexico. The prevailing climate is warm-humid $\left(23-27^{\circ} \mathrm{C}\right)$ with an altitude that varies from 10 to 900 MASL [20]. The municipality of Ocosingo, covers the largest region of the rainforest and one of the major activities is extensive livestock production.

\subsection{Sampling}

Species were selected from a previous screening of fifteen species [19] for their nutritional quality and their potential to reduce in vitro $\mathrm{CH}_{4}$ emissions when incubated alone. 
The selected species were: S. mombin, A. pennatula, P. aculeata, B. alicastrum and B. simaruba. Species were harvested with the help of cattle producers from the area. Leaves were collected from 5 to 9 individuals per species. Botanical samples were taken to verify the species in the herbarium of the Southern Border College (ECOSUR). Samples of P. purpureum grass at 60 days regrowth were taken to use as a control treatment and basal ration. Samples were dried in a forced air oven at $55^{\circ} \mathrm{C}$ or until constant weight to determine dry matter (DM) content [21]. Dried samples were ground in a Wiley Laboratory Mill (Thomas Scientific ${ }^{\circledR}$, Swedesboro, NJ, USA) to a particle size of $1 \mathrm{~mm}$ and stored for transportation and chemical analysis.

\subsection{Treatments}

Experimental diets were the inclusion of foliage of fodder tree species at two levels (15 and 30\%) mixed with Pennisetum purpureum sp. grass (85 and 70\%, respectively) simulating feeding practices commonly used by some farmers in the region. Treatments were designated as following: SM15-PP85 (15\% S. mombin + 85\% P. purpureum), SM30-PP70 (30\% S. mombin $+70 \%$ P. purpureum), AP15-PP85 (15\% A. pennatula $+85 \%$ P. purpureum), AP30PP70 (30\% A. pennatula + 70\% P. purpureum), PA15-PP85 (15\% P. aculeata + 85\% P. purpureum), PA30-PP70 (30\% P. aculeata + 70\% P. purpureum), BA15-PP85 (15\% B. alicastrum $+85 \%$ P. purpureum), BA30-PP70 (30\% B. alicastrum + 70\% P. purpureum), BS15-PP85 (15\% B. simaruba + 85\% P. purpureum), BS30-PP70 (30\% B. simaruba + 70\% P. purpureum), and control treatment 100PP (100\% P. purpureum).

\subsection{Chemical Analysis}

The in vitro gas production technique and chemical analysis were carried out at the Forage Quality and Animal Nutrition Laboratory at the International Center for Tropical Agriculture (CIAT), Palmira (Valle del Cauca, Colombia). This laboratory is certified by the FAO-IAG proficiency test of feed constituents 2017. Forage samples were incinerated in a muffle furnace at $500{ }^{\circ} \mathrm{C}$ for $4 \mathrm{~h}$ (method 942.05) [22] to determine ash and organic matter $(\mathrm{OM}=100-$ Ash (\%) content). Crude protein was determined by Kjeldahl (AN 3001 FOSS; method 984.14) from the $\mathrm{N}$ content $(\mathrm{CP}=\mathrm{N} \times 6.25)$ [23]. Neutral and acid detergent fiber (NDF and ADF, respectively) content were analyzed according to Van Soest [24] and using the Ankom Fiber Analyzer AN 3805 (Ankom ${ }^{\circledR}$ Technology Corp., Macedon, NY, USA) and gross energy (GE) by ISO 9831 [25]. To determine digestibility, the two-stage in vitro technique was used [26]. Condensed tannins (TC) content of the species was determined by the vanillin extract assay [27] at the bromatology laboratory at ECOSUR, Chiapas, Mexico. Alkaloids, cyanogenic glycosides and saponins were qualitatively quantified by the methodologies proposed by Domínguez [28]. The content of ether extract (EE) was determined by the Soxhlet immersion method (NTC 668) [29]. Metabolizable energy (ME) was estimated according to the equation proposed by Menke et al. [30]:

$$
\mathrm{ME}\left(\mathrm{MJ} \mathrm{kg}^{-1} \mathrm{DM}\right)=2.20+0.136 \times \mathrm{GP}+0.057 \times \mathrm{CP}+0.0029 \times \mathrm{CP}^{2}
$$

where GP is the net gas production in $24 \mathrm{~h}(\mathrm{~mL} / 200 \mathrm{mg})$. Likewise, net energy (NE) was calculated from the equation proposed by Menke and Steingass [31]:

$$
\mathrm{NE}\left(\mathrm{Mcal} \mathrm{lb}^{-1}\right)=\frac{2.2+(0.0272 \times \mathrm{GP})+(0.057 \times \mathrm{CP})+(0.149 \times \mathrm{EE})}{14.64}
$$

where: GP is the net gas production in $24 \mathrm{~h}\left(\mathrm{ml} \mathrm{g}^{-1} \mathrm{DM}\right), \mathrm{CP}$ is crude protein (\% DM), EE is the ether extract (\% DM); results were transformed to $\mathrm{MJ} / \mathrm{kg}^{-1} \mathrm{DM}$. Short chain fatty acids (SCFA) were calculated according to Getachew et al. [32] and transformed to mmol per liter.

$$
\mathrm{SCFA}=\frac{0.0239 \mathrm{GP}-0.0601 \mathrm{~mL}}{200 \mathrm{mg} \mathrm{DM}}
$$




\subsection{In Vitro Gas Production Technique}

Three rumen cannulated Brahman bulls of $550 \mathrm{~kg}$ live weight fed Cynodon plectostachyus and minerals were used. Animals were treated in accordance with the Colombian normative num. 84 from 1989 following the protocol approved by the ethics committee of CIAT. In vitro gas production was quantified using the methodology proposed by Menke and Steingass [31] and modified by Theodorou et al. [33]. Rumen liquid and solid material were obtained from different locations in the rumen at 8 a.m. to assure a representative sample [34]. Rumen liquor was liquefied and filtered through 10 layers of gauze and mixed in a 1:9 ratio with a mineral solution [19,31]. Treatments were incubated in independent bottles of $160 \mathrm{~mL}$ by triplicate and kept under constant flow of $\mathrm{CO}_{2}$. Bottles were placed in a water bath at $39^{\circ} \mathrm{C}$. Gas pressure and volume in the headspace of the bottles were measured with an 840,065 wide-range pressure gauge (Sper Scientific ${ }^{\circledR}$, Scottsdale, AZ, USA) connected a PS100 2-bar pressure transducer (Lutron Electronic Enterprise Co. Ltd., Taipei, Taiwan) and a three-way valve connected to a hypodermic needle that was inserted into the bottles and a $60 \mathrm{~mL}$ syringe was used to measure the gas volume. Gas pressure and volume were measured at $0,4,8,12,24,30,36$ and $48 \mathrm{~h}$. The content of the bottles was withdrawn from fermentation at 24 and $48 \mathrm{~h}$ for the degradation of DM (DDM) and OM (DOM) as described by Valencia-Salazar et al. [19]. For the degradation and gas production, two sets of triplicate bottles were used ( 24 and $48 \mathrm{~h}$ ), these were incubated from 0 to $24 \mathrm{~h}$ and from 0 to $48 \mathrm{~h}$, respectively, blanks were also included. The $\mathrm{pH}$ was measured using a pH meter (AB15 Plus, Accumet ${ }^{\circledR}$, Westford, MA, USA) at 24 and $48 \mathrm{~h}$. Bottle content was filtered in crucibles with fiberglass filter and a vacuum pump, then dried in a forced air oven at $65^{\circ} \mathrm{C}$ for $48 \mathrm{~h}$ and weighed with a precision balance. Data from the pressure and volume of the bottles was used to generate a polynomial equation for the correction of the volume of gas produced as described by Valencia-Salazar et al. [19]:

$$
\begin{gathered}
y=0.0209 x^{2}+5.9023 x-2.984 \\
R^{2}=0.9729
\end{gathered}
$$

Gas production data was adjusted to the modified Gompertz model [35] to obtain time at the inflection point (TIP, h), gas at the inflection point (GIP, $\mathrm{mL}$ ), maximum gas production rate (MGPR $\mathrm{mL} \mathrm{h}^{-1}$ ) and Lag phase (LP or the microbial establishment, $\mathrm{h}$ ).

\subsection{Methane Quantification}

Gas volume was stored in amber bottles with a capacity of $125 \mathrm{~mL}$ from samples collected from the accumulated gas at 24 and $48 \mathrm{~h}$ of incubation. Methane and $\mathrm{CO}_{2}$ concentrations were quantified in the Laboratory of GHG (CIAT) using a GC-2014 gas chromatograph (Shimadzu ${ }^{\circledR}$, Tokyo, Japan) with $1 / 8^{\prime \prime}$ packed stainless-steel columns $(1.0 \mathrm{~m}$ HayeSep T 80/100 mesh, 4 m HayeSep D 80/100, 1.5 P-N, 0.7m Shimalite Q 100/180), $80^{\circ} \mathrm{C}$ temperature, column flow of $30.83 \mathrm{~mL} \mathrm{~min}^{-1}$, injection volume handled by a loop with capacity of $2 \mathrm{~mL}$ and nitrogen was used as carrier gas.

\subsection{Statistical Analysis}

For the statistical analysis a randomized block design with 10 treatments (mixed feed substrates) and a control (100\% P. purpureum) was used with three replicates per hour (24 and $48 \mathrm{~h}$; two sets of triplicates as mentioned in 2.5) and three different inoculums from three different animals as blocking factor. The statistical model used was:

$$
\mathrm{Y}_{i j}=\mu+T i+\beta j+\varepsilon i j
$$

where $Y_{i j}$ are the observations of the response variables for treatment $i$ and block $j ; \mu$ is the overall mean; $i$ is the effect of the $i$-th treatment; $\beta j$ is the effect of the $j$-th block; and $\varepsilon i j$ is the random error of treatment $i$ in block $j$. To test treatment effects, the PROC GLM 
procedure of $S A S^{\circledR}$ software, version 9.4 was used [36]. The means of the treatments were compared by the Dunnett test with an alpha of 0.05 with respect to the control treatment.

\section{Results}

\subsection{Chemical Composition, In Vitro Digestibility, and Phytochemical Screening}

Chemical composition of forage samples and treatments is shown on Table 1. All evaluated species had higher crude protein (CP) contents than the control. The species with the lowest acid detergent fiber (ADF) content were $S$. mombin and A. pennatula, with 171.18 and $210.34 \mathrm{~g} \mathrm{~kg}^{-1} \mathrm{DM}$, respectively. P. purpureum grass provides between 1.2 and 2 times more NDF than the other species. The above described is reflected in the mixed rations. Gross energy content of mixed rations ranged from 15.86 to $17.44 \mathrm{MJ} \mathrm{kg}^{-1} \mathrm{DM}$. The highest metabolizable energy and net energy concentrations were obtained in the treatment BA30-PP70 with 7.82 and $4.82 \mathrm{MJ} \mathrm{kg}^{-1} \mathrm{DM}$, respectively. In both inclusion levels of $P$. aculeata presented the highest in vitro digestibility and $A$. pennatula had the lowest digestibility (447.44 $\left.\mathrm{g} \mathrm{kg}^{-1} \mathrm{DM}\right)$. Regarding secondary metabolites, the highest content of CT was obtained with B. simaruba (20\% CT) at inclusion of 15 and $30 \%$ in the ration with $P$. purpureum. In the phytochemical screening, presence of alkaloids was found in all species except for $B$. simaruba, and cyanogenic glycosides were found highly abundant only in A. pennatula as shown on Table 2. Also, saponin content was found in low abundance only in A. pennatula.

Table 1. Chemical composition, condensed tannin content and in vitro digestibility of forage species and treatments.

\begin{tabular}{|c|c|c|c|c|c|c|c|c|c|c|c|}
\hline \multirow[b]{2}{*}{ Species } & \multirow[b]{2}{*}{ DM } & \multicolumn{7}{|c|}{$\mathrm{g} \mathrm{kg}^{-1} \mathrm{DM}$} & \multicolumn{3}{|c|}{ MJ kg ${ }^{-1} \mathrm{DM}$} \\
\hline & & OM & NDF & ADF & $\mathrm{CP}$ & EE & IVDDM & $\mathrm{CT}$ & GE & ME & NE \\
\hline Spondias mombin (SM) & 259.75 & 852.29 & 307.77 & 171.18 & 126.95 & 44.78 & 638.59 & 9.90 & 16.25 & & \\
\hline Acacia pennatula (AP) & 505.42 & 924.85 & 492.56 & 210.34 & 192.69 & 39.25 & 447.44 & 31.1 & 20.92 & & \\
\hline Parmentiera aculeata (PA) & 308.95 & 874.47 & 614.35 & 268.81 & 183.17 & 13.85 & 548.37 & 0.00 & 18.04 & & \\
\hline Brosimum alicastrum (BA) & 489.18 & 821.28 & 298.17 & 269.22 & 116.21 & 29.92 & 686.38 & 0.00 & 15.65 & & \\
\hline Bursera simaruba (BS) & 356.71 & 900.82 & 354.37 & 249.23 & 99.07 & 25.05 & 471.37 & 200.1 & 18.92 & & \\
\hline \multicolumn{12}{|l|}{ Treatments } \\
\hline SM15-PP85 & 213.82 & 839.92 & 542.46 & 311.22 & 132.88 & 23.42 & 542.46 & 1.50 & 15.99 & 7.40 & 4.54 \\
\hline SM30-PP70 & 221.93 & 842.10 & 501.04 & 286.50 & 131.83 & 27.19 & 501.04 & 3.00 & 16.04 & 7.75 & 4.80 \\
\hline AP15-PP85 & 250.66 & 850.80 & 570.18 & 317.09 & 142.74 & 22.59 & 570.18 & 4.70 & 16.69 & 7.56 & 4.58 \\
\hline АР30-PР70 & 295.61 & 863.87 & 556.48 & 298.25 & 151.56 & 25.53 & 556.48 & 9.30 & 17.44 & 7.46 & 4.51 \\
\hline PA15-PP85 & 221.18 & 843.24 & 588.45 & 325.86 & 141.31 & 18.78 & 588.45 & 0.00 & 16.26 & 7.17 & 4.31 \\
\hline PA30-PP70 & 236.66 & 848.75 & 593.02 & 315.79 & 148.70 & 17.91 & 593.02 & 0.00 & 16.58 & 7.18 & 4.27 \\
\hline BA15-PP85 & 248.23 & 835.26 & 541.02 & 325.92 & 131.27 & 21.19 & 541.02 & 0.00 & 15.90 & 7.60 & 4.65 \\
\hline ВА30-PP70 & 290.75 & 832.80 & 498.17 & 315.92 & 128.61 & 22.73 & 498.17 & 0.00 & 15.86 & 7.82 & 4.82 \\
\hline BS15-PP85 & 228.35 & 847.20 & 549.45 & 322.92 & 128.70 & 20.46 & 549.45 & 30.0 & 16.39 & 6.92 & 4.23 \\
\hline BS30-PP70 & 251.00 & 856.66 & 515.03 & 309.92 & 123.47 & 21.27 & 515.03 & 60.0 & 16.84 & 6.05 & 3.72 \\
\hline 100PP & 205.70 & 837.73 & 583.88 & 335.93 & 133.93 & 19.65 & 583.88 & 0.00 & 15.95 & 7.08 & 4.30 \\
\hline
\end{tabular}

DM: Dry matter; OM: Organic matter; NDF: Neutral detergent fiber; ADF: Acid detergent fiber; CP: Crude protein; EE: Ether extract; IVDDM: In vitro digestibility of dry matter; CT: Condensed tannins; GE: Gross energy: ME: Metabolizable energy; NE: net energy; SM15-PP85 (15\% S. mombin + 85\% P. purpureum); SM30-PP70 (30\% S. mombin $+70 \%$ P. purpureum); AP15-PP 85 (15\% A. pennatula $+75 \%$ P. purpureum $)$; AP30-PP70 $(30 \%$ A. pennatula + 70\% P. purpureum); PA15-PP85 (15\% P. aculeata + 85\% P. purpureum); PA30-PP70 (30\% P. aculeata $+70 \%$ P. purpureum) BA15-PP85 (15\% B. alicastrum + 85\% P. purpureum); BA30-PP70 (30\% B. alicastrum + 70\% P. purpureum); BS15-PP85 (15\% B. simaruba $+85 \%$ P. purpureum); BS30-PP70 (30\% B. simaruba $+70 \%$ P. purpureum); $100 \mathrm{PP}: 100 \%$ P. purpureum. 
Table 2. Secondary metabolite content of tree species from southern Mexico.

\begin{tabular}{lccccc}
\hline \multirow{2}{*}{ Species } & \multicolumn{3}{c}{ Alkaloids } & $\begin{array}{c}\text { Cyanogenic } \\
\text { Glycosides }\end{array}$ & Saponins \\
\cline { 2 - 6 } & Mayer & Draggendorff & Wagner & - & - \\
\hline Spondias mombin (SM) & - & + & ++ & ++++ & + \\
Acacia pennatula (AP) & - & ++ & ++++ & - & - \\
Parmentiera aculeata (PA) & +++ & +++ & - & - & - \\
Brosimum alicastrum (BA) & +++ & - & - & + & - \\
Bursera simaruba (BS) & - & - & + & + & - \\
\hline
\end{tabular}

- (No presence); + (low abundance); ++ (abundant); +++ (moderately abundant); ++++ (highly abundant).

\subsection{In Vitro Gas Production Parameters}

The Gompertz model parameters for in vitro gas production are shown on Table 3. Maximum gas production (a), time at the inflection point (TIP), gas inflection point (GIP), maximum gas production rate and Lag phase (LP) differed significantly $(p<0.05)$ between evaluated treatments and control ration (100PP). The highest maximum gas production (a) value was obtained in SM30-PP70; 10\% above control $(p<0.05)$. The lowest values for MGPR were obtained when B. simaruba was included in the treatment with $13 \%$ (at $15 \%$ ) and $37 \%$ (at 30\%) below control treatment $(p<0.05)$. This treatment also presented the lowest values for maximum gas production compared to control (10\% and $18 \%$ below) $(p<0.05)$. S. mombin showed a MGRP 13\% above control $(p<0.05)$. Figure 2 shows the gas production per hour per gram of organic matter.

Table 3. Gompertz model parameters for in vitro gas production of forage species incorporated at two levels mixed with P. purpureum.

\begin{tabular}{|c|c|c|c|c|c|c|c|}
\hline \multirow[b]{2}{*}{ Rations } & \multicolumn{3}{|c|}{ Parameters } & \multirow[b]{2}{*}{$\begin{array}{l}\text { TIP } \\
\text { (h) }\end{array}$} & \multirow[b]{2}{*}{$\begin{array}{c}\text { GIP } \\
(\mathrm{mL})\end{array}$} & \multirow[b]{2}{*}{$\begin{array}{c}\text { MGPR } \\
\left(\mathrm{mL} \mathrm{h} \mathbf{h}^{-1}\right)\end{array}$} & \multirow[b]{2}{*}{ LP } \\
\hline & $a$ & $b$ & $c$ & & & & \\
\hline 100PP & 261.304 & 1.009 & 0.079 & 12.786 & 96.110 & 7.580 & 0.120 \\
\hline SM15-PP85 & 266.533 & $1.101 *$ & 0.084 & 13.170 & 98.033 & 8.200 * & $1.206^{*}$ \\
\hline SM30-PP70 & $287.369 *$ & 1.048 & 0.083 & 12.690 & 105.697 * & 8.730 * & 0.583 \\
\hline AP15-PP85 & 263.756 & 1.017 & 0.079 & 12.866 & 97.010 & 7.670 & 0.216 \\
\hline AP30-PР70 & 240.909 * & $0.953 *$ & 0.078 & 12.160 & $88.607^{*}$ & $6.947 *$ & -0.593 * \\
\hline PA15-PP85 & 220.971 * & 1.003 & $0.086^{*}$ & $11.616^{*}$ & 81.270 * & 6.613 * & 0.030 \\
\hline PA30-PP70 & $219.015^{*}$ & $0.925^{*}$ & 0.081 & 11.380 * & 80.553 * & $5.546 *$ & $-0.926^{*}$ \\
\hline BA15-PP85 & 277.702 & 0.998 & 0.081 & 12.396 & 102.140 & 8.220 * & -0.020 \\
\hline ВА30-PР70 & 283.543 * & $0.944^{*}$ & 0.083 & 11.370 * & $104.287^{*}$ & $8.676^{*}$ & $-0.676^{*}$ \\
\hline BS15-PP85 & 235.527 * & 0.979 & 0.076 & 12.826 & $86.620 *$ & 6.610 * & -0.286 \\
\hline BS30-PP70 & 214.480 * & 0.917 * & $0.060 *$ & 15.173 * & $78.887 *$ & $4.766^{*}$ & -1.386 * \\
\hline MSE & 8.089 & 0.0201 & 0.003 & 0.456 & 2.975 & 0.177 & 0.267 \\
\hline$p$-Value & $<0.0001$ & $<0.0001$ & $<0.0001$ & $<0.0001$ & $<0.0001$ & $<0.0001$ & $<0.00001$ \\
\hline
\end{tabular}

Asterisks in the same column indicate statistical difference $(p<0.05)$ with respect to the control treatment. $a$ : Maximum gas production $(\mathrm{mL}) ; b$ : difference between initial gas and final gas at an $x$ time; $c$ : specific gas accumulation rate; TIP: time at the inflection point (hours); GIP: Gas inflection point (mL); MGPR: Maximum gas production rate $\left(\mathrm{mL} \mathrm{h}^{-1}\right)$; LP: Lag phase; SM15-PP85 (15\% S. mombin + 85\% P. purpureum); SM30-PP70 (30\% S. mombin $+70 \%$ P. purpureum $)$, AP15-PP85 (15\% A. pennatula $+75 \%$ P. purpureum $) ;$ AP30-PP70 $(30 \%$ A. pennatula + 70\% P. purpureum); PA15-PP85 (15\% P. aculeata $+85 \%$ P. purpureum); PA30-PP70 (30\% P. aculeata $+70 \%$ P. purpureum) BA15-PP85 (15\% B. alicastrum $+85 \%$ P. purpureum); BA30-PP70 (30\% B. alicastrum $+70 \%$ P. purpureum $) ;$ BS15-PP85 (15\% B. simaruba $+85 \%$ P. purpureum); BS30-PP70 (30\% B. simaruba $+70 \%$ P. purpureum); $100 \mathrm{PP}: 100 \%$ P. purpureum. 


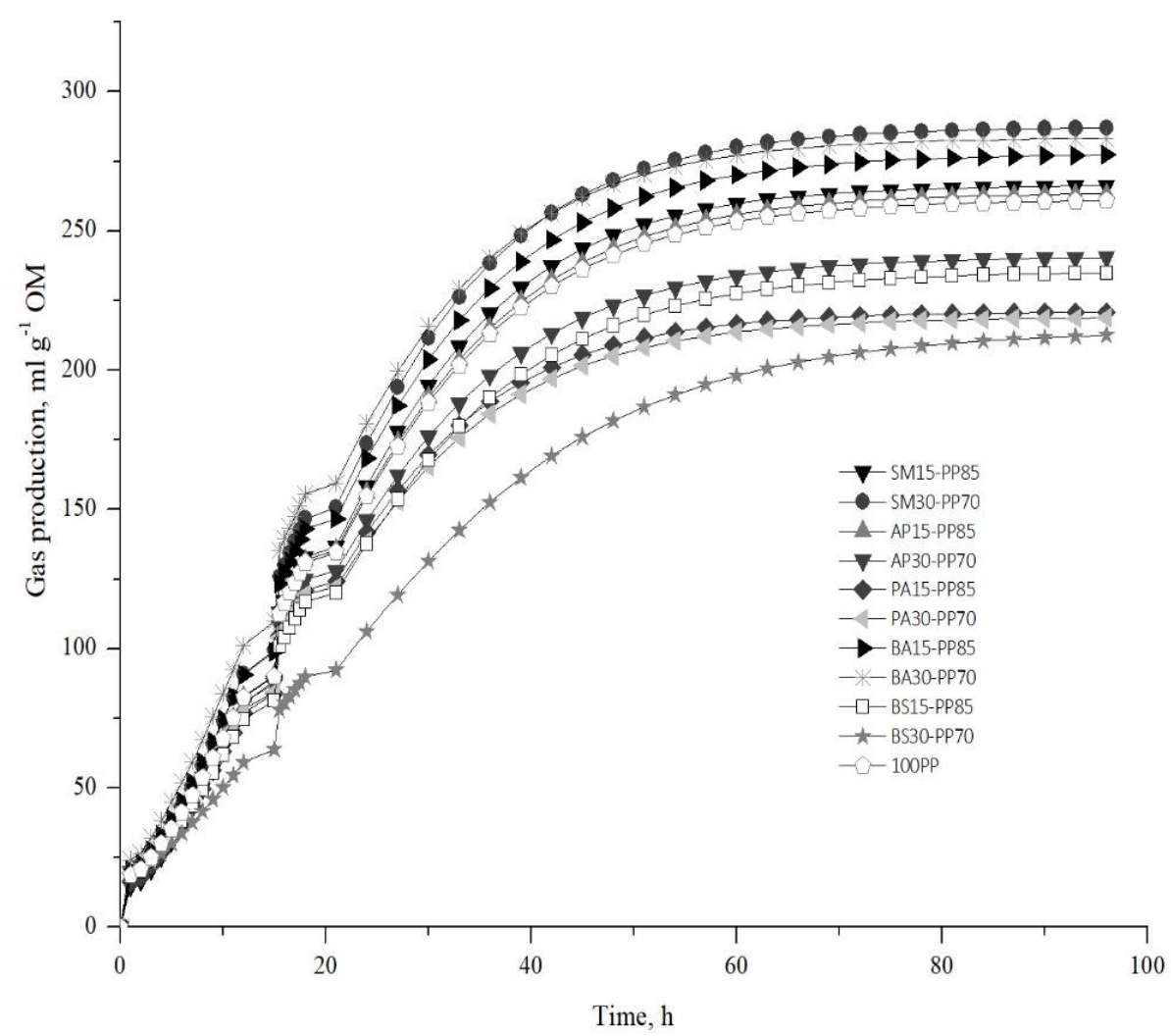

Figure 2. Gas production in $\mathrm{mL} \mathrm{g}^{-1}$ organic matter per hour. Abbreviations: SM15-PP85 (15\% S. mombin $+85 \%$ P. purpureum); SM30-PP70 (30\% S. mombin $+70 \%$ P. purpureum); AP15-PP85 (15\% A. pennatula $+75 \%$ P. purpureum); AP30-PP70 (30\% A. pennatula + 70\% P. purpureum); PA15-PP85 (15\% P. aculeata $+85 \%$ P. purpureum); PA30-PP70 (30\% P. aculeata $+70 \%$ P. purpureum); BA15-PP85 (15\% B. alicastrum $+85 \%$ P. purpureum); BA30-PP70 (30\% B. alicastrum $+70 \%$ P. purpureum); BS15-PP85 (15\% B. simaruba $+85 \%$ P. purpureum); BS30-PP70 (30\% B. simaruba $+70 \%$ P. purpureum); $100 \mathrm{PP}: 100 \%$ P. purpureum.

\subsection{Dry Matter Degradability, $p H$, Short Chain Fatty Acids and CH4 Production}

The highest degradability at $48 \mathrm{~h}$ was observed when S. mombin and B. alicastrum species were included in the two levels. The lowest degradabilities at $48 \mathrm{~h}$ were obtained in PA30-PP70, AP30-PP70 and PA15-PP85 with 8.77, 7.91 and 7.34\% below the control (PP100) $(p<0.05)$. The $\mathrm{pH}$ was not affected by the inclusion of the forage tree species at two levels and the concentrations of SCFA were $20 \%$ and $23 \%$ above control $(p<0.05)$ for treatments SM30-PP70 and BA30-PP70, respectively. Methane was expressed in $\mathrm{mg} \mathrm{g}^{-1}$ of incubated and DOM as suggested by Yáñez-Ruiz et al. [34] and is presented in Table 4. Methane production in $\mathrm{mg} \mathrm{g}^{-1} \mathrm{DOM}$ and $\mathrm{mg} \mathrm{g}^{-1} \mathrm{IOM}$ (incubated OM) was different between the treatments and P. purpureum $(p<0.0001)$. It was observed that PA30-PP70 had the major $\mathrm{CH}_{4} \mathrm{mg} \mathrm{g}^{-1} \mathrm{IOM}$ produced at $24 \mathrm{~h}$ and at $48 \mathrm{~h}, 86 \%$ and $33 \%$ above control $(p<0.05)$. Methane emissions at 48 were also higher and significantly different $(p<0.05)$ in SM30-PP70, BA15-PP85 and BA30-PP70 when compared to control (100PP), the other treatments produced similar amounts of $\mathrm{CH}_{4}$. On the other hand, BS30-PP70 had the lowest $\mathrm{CH}_{4} \mathrm{mg} \mathrm{g}^{-1}$ IOM production; $21 \%$ below control at $48 \mathrm{~h}$, however, no statistical difference was observed. 
Table 4. DM degradability, $\mathrm{pH}, \mathrm{SCFA}$ and $\mathrm{CH}_{4}$ production at 24 and $48 \mathrm{~h}$ of incubation of forage species mixed with $P$. purpureum at two levels.

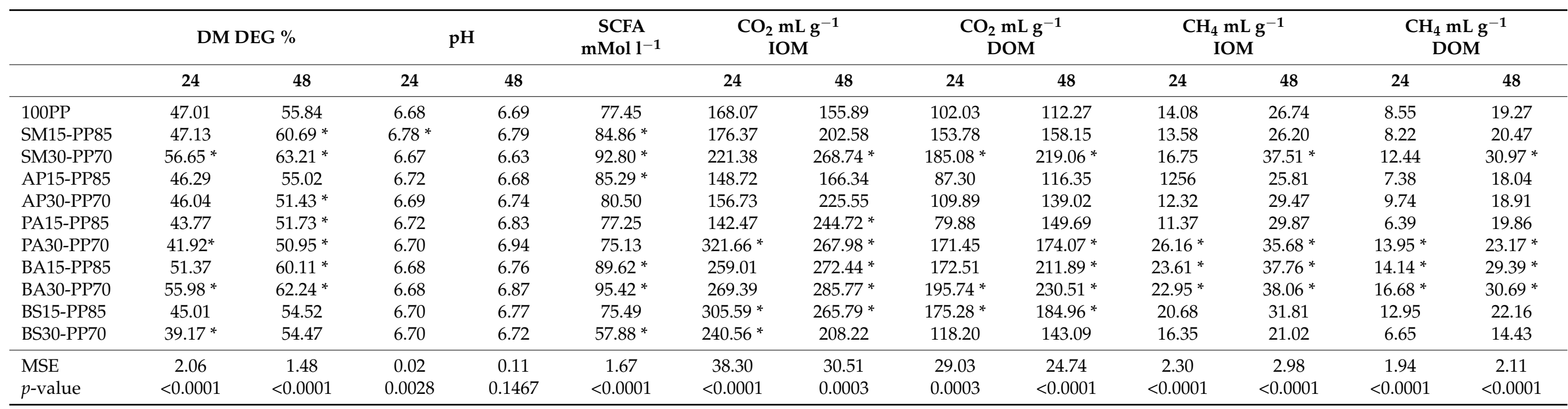

Asterisks in the same column indicate statistical difference $(p<0.05)$ with respect to the control treatment. DEG: degradation, IOM: incubated organic matter, DOM: Degraded organic matter; SCFA: Short chain fatty acids; SM15-PP85 (15\% S. mombin + 85\% P. purpureum); SM30-PP70 (30\% S. mombin + 70\% P. purpureum); AP15-PP85 (15\% A. pennatula + 75\% P. purpureum); AP30-PP70 (30\% A. pennatula + 70\% P. purpureum); PA15-PP85 (15\% P. aculeata+ 85\% P. purpureum); PA30-PP70 (30\% P. aculeata + 70\% P. purpureum); BA15-PP85 (15\% B. alicastrum + 85\% P. purpureum); BA30-PP70 (30\% B. alicastrum + 70\% P. purpureum); BS15-PP85 (15\% B. simaruba $+85 \%$ P. purpureum); BS30-PP70 (30\% B. simaruba + 70\% P. purpureum); $100 \mathrm{PP}: 100 \%$ P. purpureum; Means in the same column with same superscript are significantly different $(p<0.05)$ when compared to control (100PP). 


\section{Discussion}

\subsection{Chemical Composition and In Vitro Digestibility}

In the present study the incorporation of the five forage tree species, independently at two different levels of inclusion (15 and 30\%), into a diet based on forage grass P. purpureum improved nutritional composition, thus these tree forages are suitable for ruminant feeding. Crude protein content of the treatments was always above $7 \%$, the minimum necessary for the correct function of rumen environment [24]. The mixture of grass with the foliage of native tree species at different levels can be a viable and a low-cost strategy to minimize the scarcity of nutrients in tropical cattle production systems. Gaviria-Uribe et al. [37] stated that including tree forages on ruminant's diet that are based on low quality grass, increases CP and decreases total carbohydrate intake. However, P. purpureum used in the present trial showed higher $\mathrm{CP}$ and lower values of structural carbohydrate content compared to other studies [18,38]. This is directly related to the age of regrowth of the pasture [39], as well as a higher digestibility and gas production as observed in this trial due to the high quality of the diets evaluated for tropical regions. The CP and EE values of $S$. mombin are similar to those obtained by Yusuf et al. [40] however, NDF and ADF contents were lower in the present study. The inclusion of $A$. pennatula at $30 \%$ had the highest CP content among the evaluated treatments, however the in vitro digestibility was reduced compared to the inclusion of $15 \%$ and this can be explained by its content of CT (31.1\%) and cyanogenic $(+++)$ glycosides that can alter the capacity of the microbiome to ferment nutrient components [15].

Metabolizable and net energy concentrations varied among evaluated treatments and was particularly high in BA30-PP70 (7.82 and 4.82 $\mathrm{MJ} \mathrm{kg}^{-1} \mathrm{DM}$, respectively), consistent with a higher gas production observed in this treatment. A higher net energy content promotes a higher digestibility of the total nutrients as a result of increased nutritive values. Metabolizable energy ranged between 6 and $7.8 \mathrm{MJ} \mathrm{kg}^{-1} \mathrm{DM}$ in the present investigation, this variations between species may be due to the differences in CP content and to a lesser extent to systematic errors made in the sampling of the gas produced as suggested by Tagliapietra et al. [41]. According to Krizsan et al. [42], microbial protein synthesis is favored by a higher ME input. Although, BA30-PP70 showed a higher net $\mathrm{CH}_{4}$ production, its chemical composition and ME can improve animal performance and reduce $\mathrm{CH}_{4} \mathrm{per} \mathrm{kg}$ of product.

\subsection{Dry Matter Degradability, In Vitro Gas Production and $p H$}

Dry matter degradation is inversely related to structural carbohydrate content $[43,44]$, this is corroborated in treatments with species such as $S$. mombin or B. alicastrum which have higher digestibility and low NDF and/or FDA content or with mixtures constituted with PA, in which the opposite effect of carbohydrates was observed. Rumen degradation of DM at $48 \mathrm{~h}$ was improved in SM15-PP85, SM30-PP70, BA15-PP85, BA30-PP70 compared to control $(p \leqslant 0.0001)$. The degradation of $A$. pennatula at 24 and $48 \mathrm{~h}$ was affected due to its content of secondary metabolites (CT: $31.1 \mathrm{~g} \mathrm{~kg}^{-1} \mathrm{DM}$, alkaloids: ++ , cyanogenic glycosides: ++++ and saponins: + ) that can interfere in the degradation of carbohydrates and proteins. These findings are similar to those obtained by Albores-Moreno et al. [38] who supplemented N. emargiata, L. leucocephala, P. piscipula and H. albicans at 30\% and increased CT content of a diet based on P. purpureum. Additionally, saponins can modify rumen fermentation by suppressing protozoa and selectively inhibiting some bacteria [45]. Secondary metabolites can make the diet less susceptible to the degradation of microorganism in the rumen due to their capacity to form complexes with the components of the diet, alter the mechanisms of degradation of the microorganism or reduce their population [46]. In addition, there is a direct relation between DMD and gas production, i.e., the higher the digestibility, the higher the gas production rate expected. This is explained by the nutritional quality of the forages, especially by the structural carbohydrate content, e.g., the diets that included $P$. aculeata presented a higher NDF content that will trigger a lower gas production. This observation agrees with authors such as Sánchez et al. [47] and Molina-Botero et al. [48]. 
The effect of plant secondary metabolites on maximum gas production can be observed when the fermentation parameters of $P$. purpureum are compared. Treatments with A. pennatula, $P$. aculeata and B. simaruba had the lowest gas productions and the highest content of secondary metabolites compared to P. purpureum. Regarding the CT content found in A. pennatula and B. simaruba, these have the capacity to inhibit enzymatic and microbial activity and consequently reduce fermentation [49]. Alkaloids present in P. aculeata can have negative effect on gas production as reported by Aguiar and Wink [50] due to a possible effect of these alkaloids on ruminal microorganisms. Aguiar and Wink [50] established that any outcome on the total gas production in the rumen can be interpreted as an effect on the microbial community. Fermentation kinetics of A. pennatula, P. aculeata, S. mombin, B. alicastrum, and B. simaruba incubated alone as single treatments were presented by Valencia-Salazar et al. [19]. The lowest maximum gas production observed by Valencia-Salazar et al. [19] was in B. simaruba and A. pennatula with 118.03 and $148.83 \mathrm{~mL}$, respectively and $B$. alicastrum presented the highest maximum gas production $(256.72 \mathrm{~mL})$. These results were also observed in this study with $B$. simaruba and B. alicastrum, however, A. pennatula presented higher total gas production than P. aculeata in this study.

The observed $\mathrm{pH}$ values of the evaluated treatments are like those reported for tropical diets. Likewise, in the present investigation there is no relation between $\mathrm{pH}$ and SCFA variables, as described by Li et al. [51]. This observation is perhaps because $\mathrm{pH}$ values were not below 6.0, which is a critical value for the activity of the fibrolytic microbial population and, therefore, for fiber degradation. As the degradation of the fiber is the main precursor of SCFA in the rumen, the observation described above can also be related with methanogenesis [52]. On the other hand, and according to Meale et al. [53] SCFA had consistent concentrations on leguminous, non-leguminous and grass species (68.7-105.5 mMol). However, the methodology used for the quantification of SCFA must be considered since secondary metabolites can affect its production [52]. According to $\mathrm{Li}$ et al. [51], VFA production in the rumen is directly related to the ME consumed, and this study corroborated this postulate as the BS30-PP70 treatment had a low ME contribution $\left(6.05 \mathrm{MJ} \mathrm{kg}^{-1} \mathrm{DM}\right)$ and resulted in a low content of SCFA $\left(57.88 \mathrm{mMol} \mathrm{L}^{-1}\right)$, while with the BA30-PP70 treatment, the opposite occurred (7.2 $\mathrm{MJ} \mathrm{kg}^{-1} \mathrm{DM}$ and $95.42 \mathrm{mMol} \mathrm{L}^{-1}$ ).

\subsection{Methane Production}

Methane production of treatment with P. aculeata was low, perhaps due to the higher NDF content, and to the alkaloid content as described before. Cyanogenic glycosides present in A. pennatula are either toxic to methanogens or impair their growth potential by reducing the availability of sulphur [54]. Several studies have shown the reduction effect on $\mathrm{CH}_{4}$ synthesis of cyanogenic glycosides from cassava [54] however, further work is needed to understand the mode of action of these components on the rumen microbiome and on animal performance. On the other hand, diet components that contain alkaloids have showed in other studies to reduce $\mathrm{CH}_{4}$ formation $[55,56]$. Through the rumen simulation technique (RUSITEC), Khiaosa-ard et al. [56] showed that alkaloid supplementation at a low dose shifted the fermentation pathway to more propionate and less acetate and at a high dose an effect is observed on specific methanogenic archaea without affecting their abundance.

Results in $\mathrm{CH}_{4}$ reduction were observed in the screening carried out by ValenciaSalazar et al. [19] with S. mombin, P. aculeata and B. simaruba and high $\mathrm{CH}_{4}$ production with B. alicastrum). The high content of CT found B. simaruba can explain the lower $\mathrm{CH}_{4}$ production at 24 and $48 \mathrm{~h}$ compared to control treatment, however, no statistical differences were observed in this study. Forages that contain CT have demonstrated to reduce $\mathrm{CH}_{4}$ production both in vivo and in vitro trials [57]. Condensed tannins can reduce protozoal [58] and bacterial activity of archaea [59] by inhibiting enzyme activity, decreased degradation of substrates and direct action on the cell membrane [60]. The secondary effect of $\mathrm{CT}$ on $\mathrm{CH}_{4}$ is the reduction in fiber digestion and fermentation, the decrease in the inter-specific transfer of hydrogens between protozoa and methanogenic archaea and 
the consequent increase in the concentration of propionic acid in the rumen [61]. PiñeiroVázquez et al. [62] included $30 \%$ of B. simaruba in sheep diets and concluded that the effect of $\mathrm{CT}$ from this species reduced $\mathrm{CH}_{4}$ emissions despite not observing a numerical difference, those results are similar to the ones obtained in the present investigation. However, different animal species may vary in their response to the same mitigation strategy [34] and the results obtained in the present study must be verified in a in vivo trial using cattle. Bhatta et al. [63] found a positive correlation $\left(\mathrm{R}^{2}=0.98\right)$ in $\mathrm{CH}_{4}$ production measured using the $\mathrm{SF}_{6}$ tracer technique and the in vitro gas production technique proposed by Menke and Steingass [31] as used in this trial. Among $\mathrm{CH}_{4}$ quantification techniques, the in vitro fermentation technique involving incubation of substrates in rumen fluid has been extensively used for the evaluation of ruminant feeds, complement standard laboratory analysis, and constitute a cheaper alternative to evaluate large number of samples [34].

In developing countries, livestock is predominantly kept on high-roughage diets with no concentrate supplementation which increases ruminal methanogenesis, converting forage tree species that contain secondary metabolites in an alternative in many parts of the tropics for the improvement of animal performance and the reduction of enteric $\mathrm{CH}_{4}$ emissions [18,45]. The extent of methane mitigation when feeding secondary metabolites, can be variable between in vivo and in vitro studies, so further research is necessary on the specific effect on rumen microorganisms and the chemical structure of these compounds.

\section{Conclusions}

The species evaluated in the present study presented nutritional quality that favored fermentation parameters such as total gas production, degradability, and short chain fatty acid production. Treatments that included Bursera simaruba, Acacia pennatula and Parmentiera aculeata contained considerable amounts of secondary metabolites such as condensed tannins, cyanogenic glycosides, and alkaloids. There was an inverse relation between NDF content and DM degradation, net gas and methane production and the content of secondary metabolites and methane production. However, the inclusion of these forage species had no statistical effect on the reduction of $\mathrm{CH}_{4}$ emissions per unit of DM incubated or degraded at 24 and $48 \mathrm{~h}$ with respect to P. purpureum. However, their high nutritional quality can improve tropical diets based on low quality pastures.

Author Contributions: Conceptualization, S.S.V.-S., G.J.-F., J.C.K.-V.; methodology, S.S.V.-S., J.A. and I.C.M.-B.; software, I.C.M.-B. and S.S.V.-S.; validation, I.C.M.-B. and S.S.V.-S.; formal analysis, I.C.M.B.; investigation, S.S.V.-S. and G.J.-F.; resources, J.A.; data curation, I.C.M.-B.; writing-original draft preparation, S.S.V.-S. and J.C.K.-V.; writing-review and editing, S.S.V.-S. and J.C.K.-V.; supervision, J.A., N.C. and G.J.-F.; project administration, J.A.; funding acquisition, J.A. and N.C. All authors have read and agreed to the published version of the manuscript.

Funding: This work was implemented as part of the CGIAR Research Program (CRP) on Climate Change, Agriculture and Food Security (CCAFS), and the Livestock CRP which are carried out with support from CGIAR Fund Donors and through bilateral funding agreements. For details, please visit https:/ / ccafs.cgiar.org/donors (accessed on 1 December 2021). Likewise, the field work was financed by The College of the Southern Border (ECOSUR), Mexico www.ecosur.mx (accessed on 1 December 2021).

Institutional Review Board Statement: The work described here was conducted using rumen fluid obtained from fistulated cattle maintained in accordance with the requirements of Colombian law No 84/1989 and following protocols approved by the Ethics Committee of the International Center for Tropical Agriculture, assuring the welfare of animals used in the experiment. The manuscript does not contain clinical studies or patient data.

Data Availability Statement: All authors ensure that all data and materials support the findings and comply with field standards. The data presented in this study are available on request from the corresponding author.

Acknowledgments: This research was supported by the CGIAR Research Program on Climate Change, Agriculture and Food Security (CCAFS) and the Global Research Alliance on Agricultural 
Greenhouse Gases (GRA) through their CLIFF-GRADS program. CCAFS capability building objectives are carried out with support from CGIAR Trust Fund and through bilateral funding agreements. For details, please visit https:/ / ccafs.cgiar.org/donors (accessed on 1 December 2021). Thank you to CIAT for hosting the recipient and to the Government of New Zealand for providing financial support. We also acknowledge the financial assistance of OneCGIAR initiative on Livestock, Climate and System Resilience (LCSR). The doctoral scholarship granted to the first author by the National Council of Science and Technology of Mexico (CONACYT) is appreciated.

Conflicts of Interest: The authors declare no conflict of interest. The funders had no role in the design of the study; in the collection, analyses, or interpretation of data; in the writing of the manuscript, or in the decision to publish the results.

\section{References}

1. Beauchemin, K.; Ungerfeld, E.; Eckard, R.; Wang, M. Fifty years of research on rumen methanogenesis: Lessons learned and future challenges for mitigation. Animal 2020, 14 (Suppl. S1), s2-s16. [CrossRef]

2. Glatzle, A. Questioning key conclusions of FAO publications 'Livestock's Long Shadow' (2006) appearing again in 'Tackling Climate Change Through Livestock'. Pastoralism 2013, 4, 1. [CrossRef]

3. Haque, N. Dietary manipulation: A sustainable way to mitigate methane emissions from ruminants. Anim. Feed Sci. Technol. 2018, 60, 15. [CrossRef]

4. Kurihara, M.; Magner, T.; Hunter, R.; McCrabb, G. Methane production and energy partition of cattle in the tropics. Br. J. Nutr. 1999, 81, 227-234. [CrossRef]

5. Hyland, J.J.; Styles, D.; Jones, D.J.; Williams, A.P. Improving livestock production efficiencies presents a major opportunity to reduce sectoral greenhouse gas emissions. Agric. Syst. 2016, 147, 123-131. [CrossRef]

6. Cammack, K.M.; Austin, K.J.; Lamberson, W.R.; Conant, G.C.; Cunningham, H.C. Ruminnat nutrition symposium: Tiny but mighty: The role of the rumen microbes in livestock production. Anim. Sci. J. 2018, 96, 752-770. [CrossRef]

7. Henderson, G.; Cox, F.; Ganesh, S.; Jonker, A.; Young, W.; Janssen, P.H. Rumen microbial community composition varies with diet and host, but a core microbiome is found across a wide geographical range. Sci. Rep. 2015, 5, 1-15. [CrossRef] [PubMed]

8. Lan, W.; Yang, C. Ruminal methane production: Associated microorganisms and the potential of applying hydrogen-utilizing bacteria for mitigation. Sci. Total Environ. 2019, 654, 1270-1283. [CrossRef] [PubMed]

9. Huws, S.A.; Creevey, C.J.; Oyama, L.B.; Mizrahi, I.; Denman, S.E.; Popova, M.; Mayorga, O.L.; Morrisson, S.; Elliott, C.; Morgavi, D.P.; et al. Addressing global ruminant agricultural challenges through understanding the rumen microbiome: Past, present, and future. Front. Microb. 2018, 9, 2161. [CrossRef] [PubMed]

10. Belanche, A.; De La Fuente, G.; Newbold, C.J. Study of methanogen communities associated with different rumen protozoal populations. FEMS Microbiol. Ecol. 2014, 90, 663-677. [CrossRef]

11. Tapio, I.; Snelling, T.J.; Strozzi, F.; Wallace, R.J. The ruminal microbiome associated with methane emissions from ruminant livestock. J. Anim. Sci. Biotechnol. 2017, 8, 7. [CrossRef]

12. Berghuis, B.A.; Yu, F.B.; Schulz, F.; Blainey, P.C.; Woyke, T.; Quake, S.R. Hydrogenotrophic methanogenesis in archaeal phylum Verstraetearchaeota reveals the shared ancestry of all methanogens. Proc. Natl. Acad. Sci. USA 2019, 116, 5037-5044. [CrossRef]

13. Arndt, C.; Hristov, A.N.; Price, W.J.; McClelland, S.C.; Pelaez, A.M.; Cueva, S.F.; Martin, C.; Schwarm, A.; Veneman, J.B.; ZhongTang, Y.; et al. Strategies to mitigate enteric methane emissions by ruminants-a way to approach the $2.0^{\circ} \mathrm{C}$ target. Preprint 2021, in press.

14. Arango, J.; Ruden, A.; Martinez-Baron, D.; Loboguerrero, A.M.; Berndt, A.; Chacón, M.; Torres, C.F.; Oyhantcabal, W.; Gomez, C.A.; Ricci, P.; et al. Ambition Meets Reality: Achieving GHG Emission Reduction Targets in the Livestock Sector of Latin America. Front. Sustain. Food Syst. 2020, 4, 65. [CrossRef]

15. Ku-Vera, J.C.; Jiménez-Ocampo, R.; Valencia-Salazar, S.; Flores-Santiago, E.J.; Montoya-Flores, M.D.; Molina-Botero, I.C.; Arango, J.; Gomez-Bravo, C.A.; Aguilar-Perez, C.F.; Solorio-Sanchez, F.J. Role of Secondary Plant Metabolites on Enteric Methane Mitigation in Ruminants. Front. Vet. Sci. 2020, 7, 584. [CrossRef]

16. Patra, A.K.; Park, T.; Kim, M.; Yu, Z. Rumen methanogens and mitigation of methane emissions by anti-methanogenic compounds and substances. J. Anim. Sci. Biotechnol. 2017, 8, 13. [CrossRef]

17. Rao, I.; Peters, M.; Castro, A.; Schultze-Kraft, R.; White, D.; Fisher, M.; Jenet, A.; Schmidt, A.; Vivas, N.; Rudel, T. LivestockPlusThe sustainable intensification of forage-based agricultural systems to improve livelihoods and ecosystem services in the tropics. Trop. Grassl. 2015, 3, 59. [CrossRef]

18. Valencia-Salazar, S.; Piñeiro, A.T.; Molina, I.C.; Lazos, F.J.; Uuh, J.J.; Segura, M.; Ramírez, L.; Solorio, F.J.; Ku, J.C. Potential of Samanea saman pod meal for enteric methane mitigation in crossbred heifers fed low-quality tropical grass. Agric. Forest. Meteorol. 2018, 258, 108-116. [CrossRef]

19. Valencia-Salazar, S.S.; Jiménez-Ferrer, G.; Arango, J.; Molina-Botero, I.C.; Chirinda, N.; Piñeiro-Vázquez, A.; Jiménez-Ocampo, R.; Nahed-Toral, J.; Ku-Vera, J. Enteric methane mitigation and fermentation kinetics of forage species from Southern Mexico: In vitro screening. Agroforest Syst. 2021, 95, 293-305. [CrossRef] 
20. García del Valle, Y.; Naranjo, E.; Caballero, J.; Martorell, C.; Ruan-Soto, F.; Enríquez, P. Cultural significance of wild mammals in mayan and mestizo communities of the Lacandon Rainforest, Chiapas, Mexico. J. Ethnobiol. Ethnomed. 2015, 11, 36. [CrossRef]

21. ISO. ISO 6496. Animal Feeding Stuffs-Determination of Moisture and Other Volatile Matter Content; International Organization for Standardization: Geneva, Switzerland, 1999.

22. AOAC. Official Methods of Analysis, 16th ed.; Association of Official Analytical Chemists (AOAC): Washington, DC, USA, 2005.

23. AOAC. Official Methods of Analysis, 15th ed.; Association of Official Analytical Chemists (AOAC): Washington, DC, USA, 1990.

24. Van Soest, P.J.; Robertson, J.B.; Lewis, B.A. Methods for dietary fibre, neutral detergent fibre and non-starch polysaccharides in relation to animal nutrition. J. Dairy Sci. 1999, 74, 3583-3597. [CrossRef]

25. ISO. ISO 9831. Animal Feeding Stuffs, Animal Products, and Faeces or Urine-Determination of Gross Calorific Value-Bomb Calorimeter method; International Organization for Standardization: Geneva, Switzerland, 1998.

26. Tilley, J.M.A.; Terry, R.A. A two-stage technique for the in vitro digestion of forage crops. J. Br. Grassl. Soc. 1963, 18, 104-111. [CrossRef]

27. Hagerman, A.E.; Butler, L.G. Protein precipitation method for the quantitative determination of tannins. J. Agric. Food Chem. 1978, 26, 809-812. [CrossRef]

28. Domínguez, X.A. Métodos de Investigación Fitoquímica; Editorial Limusa: Mexico City, Mexico, 1979.

29. ICONTEC. NTC 668. Alimentos y Materias Primas. Determinación de los Contenidos de Grasa y Fibra Cruda; Instituto Colombiano de Normas Técnicas y Certificación (ICONTEC): Bogotá, Colombia, 1973; p. 8.

30. Menke, K.H.; Raab, L.; Salewski, A.; Steingass, H.; Fritz, D.; Schneider, W. The estimation of the digestibility and metabolisable energy content of ruminant feedstuffs from the gas production when they are incubated with rumen liquor. J. Agric. Sci. 1979, 93, 217. [CrossRef]

31. Menke, K.H.; Steingass, H. Estimation of the energetic feed value obtained from chemical analysis and in vitro gas production using rumen fluid. Anim. Res. Dev. 1988, 28,7-55.

32. Getachew, G.; Makkar, H.P.S.; Becker, K. Tropical browses: Contents of phenolic compounds, in vitro gas production and stoichiometric relationship between short chain fatty acid and in vitro gas production. J. Agric. Sci. 2002, 139, 341-352. [CrossRef]

33. Theodorou, M.K.; Williams, B.A.; Dhanoa, M.S.; McAllan, A.B.; France, J.A. Simple gas production method using a pressure transducer to determine the fermentation kinetics of ruminant feeds. Anim. Feed Sci. Technol. 1994, 48, 185-197. [CrossRef]

34. Yáñez-Ruiz, D.R.; Bannink, A.; Dijkstra, J.; Kebreab, E.; Morgavi, D.P.; O’Kiely, P.; Reynolds, C.K.; Schwarm, A.; Shingfield, K.J.; $\mathrm{Yu}, \mathrm{Z}$; ; et al. Design, implementation and interpre-tation of in vitro batch culture experiments to assess enteric methane mitigation in ruminants-A review. Anim. Feed Sci. Technol. 2016, 216, 1-18. [CrossRef]

35. Lavrenčič, A.; Mills, C.R.; Stefanon, B. Application of the Gompertz model to describe the fermentation characteristics of chemical components in forages. Anim. Sci. J. 1998, 66, 155-161. [CrossRef]

36. SAS Institute. User's Guide: Statistics Version 9.4; SAS Inst. Inc.: Cary, NC, USA, 2012.

37. Gaviria-Uribe, X.; Bolivar, D.; Rosenstock, T.; Molina-Botero, I.C.; Chirinda, N.; Barahona, R.; Arango, J. Nutritional quality, voluntary intake and enteric methane emissions of diets based on novel Cayman grass and its associations with two Leucaena shrub legumes. Vet. Sci. Front. 2020, 7, 579189. [CrossRef] [PubMed]

38. Albores-Moreno, S.; Alayón-Gamboa, J.A.; Miranda-Romero, L.A.; Alarcón-Zúñiga, B.; Jiménez-Ferrer, G.; Ku-Vera, J.C.; PiñeiroVázquez, A.T. 2018 Effect of tree foliage supplementation of tropical grass diet on in vitro digestibility and fermentation, microbial biomass synthesis and enteric methane production in ruminants. Trop. Anim. Health Prod. 2018, 58, 893-904. [CrossRef]

39. Ortega-Gómez, R.; Castillo-Gallegos, E.; Jarillo-Rodríguez, J.; Escobar-Hernández, R.; Ocaña-Zavaleta, E.; Valles de la Mora, B. Nutritive Quality of Ten Grasses During the Rainy Season In A Hot-Humid Climate And Ultisol Soil. Trop. Subtrop. Agroecosyst. 2011, 13, 481-491.

40. Yusuf, A.O.; Egbinola, O.O.; Ekunseitan, D.A.; Salem, A.Z.M. Chemical characterization and in vitro methane production of selected agroforestry plants as dry season feeding of ruminants livestock. Agroforest Syst. 2020, 94, 1481-1489. [CrossRef]

41. Tagliapietra, F.; Cattani, M.; Hansen, H.H.; Hindrichsen, I.K.; Bailoni, L.; Schiavon, S. Metabolizable energy content of feeds based on 24 or $48 \mathrm{~h}$ in situ NDF digestibility and on in vitro $24 \mathrm{~h}$ gas production methods. Anim. Feed Sci. Technol. 2011, 170, 182-191. [CrossRef]

42. Krizsan, S.J.; Pang, D.; Fatehi, F.; Rinne, M.; Huhtanen, P. Metabolisable energy of grass and red clover silages fed to sheep at maintenance level. Animal 2020, 14, 753-762. [CrossRef] [PubMed]

43. Narváez, N.; Lascano, C.E. Caracterización química de especies arbóreas tropicales con potencial forrajero en Colombia. Pasturas Trop. 2004, 26, 1-8.

44. Lee, M.R.F.; Jordana Rivero, M.; Cone, J.W. The role of pasture in the diet of ruminant livestock. In Improving Grassland and Pasture Management in Temperature Agriculture; Marshall, A., Collins, R., Eds.; Burleigh Dodds Science Publishing Limited: Cambridge, UK, 2018. [CrossRef]

45. Goel, G.; Makkar, H.P. Methane mitigation from ruminants using tannins and saponins. Trop. Anim. Health Prod. 2012, 44, 729-739. [CrossRef] [PubMed]

46. Tedeschi, L.O.; Muir, J.P.; Naumann, H.D.; Norris, A.B.; Ramírez-Restrepo, C.A.; Mertens-Talcott, S.U. Nutritional Aspects of Ecologically Relevant Phytochemicals in Ruminant Production. Front. Vet. Sci. 2021, 8, 628445. [CrossRef] [PubMed]

47. Sánchez, D.E.; Arreaza, L.C.; Abadía, B. Estudio de la cinética de degradación in vitro de cuatro forrajes tropicales y una leguminosa de clima templado. Cienc. Tecnol. Agropecu. 2005, 6, 58-68. [CrossRef] 
48. Molina-Botero, I.C.; Mazabel, J.; Arceo-Castillo, J.; Urrea-Benitez, J.L.; Olivera-Castillo, L.; Barahona-Rosales, R.; Chirinda, N.; KuVera, J.; Arango, J. Effect of the addition of Enterolobium cyclocarpum pods and Gliricidia sepium forage on dry matter degradation, volatile fatty acid concentration, and in vitro methane production. Trop. Anim. Health Prod. 2020, 52, 2787-2798. [CrossRef]

49. Patra, A.K.; Yu, Z. Effect s of vanillin, quillaja saponin, and essential oils on in vitro fermentation and protein degrading microorganisms of the rumen. Appl. Microbiol. Biotechnol. 2014, 98, 897-905. [CrossRef]

50. Aguiar, R.; Wink, M. Do naïve ruminants degrade alkaloids in the rumen? J. Chem. Ecol. 2005, 31, 761-787. [CrossRef] [PubMed]

51. Li, M.M.; White, R.R.; Guan, L.L.; Harthan, L.; Hanigan, M.D. Metatranscriptomic analyses reveal ruminal pH regulates fiber degradation and fermentation by shifting the microbial community and gene expression of carbohydrate-active enzymes. Anim. Microbiome 2021, 3, 32. [CrossRef]

52. Bodas, R.; Prieto, N.; García-González, R.; Andrés, S.; Giráldez, F.J.; López, S. Manipulation of rumen fermentation and methane production with plant secondary metabolites. Anim. Feed Sci. Technol. 2012, 176, 78-93. [CrossRef]

53. Meale, S.J.; Chaves, A.V.; Baah, J.; McAllister, T.A. Methane production of different forages in in vitro ruminal fermentation. Asian-Aust. J. Anim. Sci. 2012, 25, 86. [CrossRef]

54. Vongsamphanh, P.; Inthapanya, S.; Preston, T.; Van Dung, D.; Xuan Ba, N. Effect of leaves from sweet or bitter cassava and brewers' grains on methane production in an in vitro rumen incubation of cassava root pulp-urea. Livest. Res. Rural Dev. 2018, $30,167$.

55. Randami, D.; Chaudhry, A.S.; Seal, C.J. Alkaloid and polyphenol analysis by HPLC in green and black tea powders and their potential use as additives in ruminant diets. AIP Conf. Proc. 2018, 1927, 030008. [CrossRef]

56. Khiaosa-Ard, R.; Mahmood, M.; Lerch, F.; Traintinger, F.P.; Petri, R.M.; Münnich, M.; Zebeli, Q. Physicochemical stressors and mixed alkaloid supplementation modulate ruminal microbiota and fermentation in vitro. Anaerobe 2020, 65, 102263. [CrossRef]

57. Patra, A.K.; Saxena, J. A new perspective on the use of plant secondary metabolites to inhibit methanogenesis in the rumen. Phytochemistry 2010, 71, 1198-1222. [CrossRef] [PubMed]

58. Puchala, R.; Animut, G.; Patra, A.K.; Detweiler, G.D.; Wells, J.E.; Varel, V.H.; Sahlu, T. Methane emissions by goats consuming Sericea lespedeza at different feeding frequencies. Anim. Feed Sci. Technol. 2012, 175, 76-84. [CrossRef]

59. Min, B.R.; Solaiman, S.; Shange, R.; Eun, J.S. Gastrointestinal bacterial and methanogenic archaea diversity dynamics associated with condensed tannin-containing pine bark diet in goats using $16 \mathrm{~S}$ rDNA amplicon pyrosequencing. Int. J. Food Microbiol. 2014, 11, 1-11. [CrossRef] [PubMed]

60. McSweeney, C.S.; Palmer, B.; Bunch, R.; Krause, D.O. Microbial interactions with tannins: Nutritional consequences for ruminants. Anim. Feed. Sci. Technol. 2001, 91, 83-93. [CrossRef]

61. Vargas, J.; Cárdenas, E.; Pabón, M.; Carulla, J. Emisión de metano entérico en rumiantes en pastoreo. Arch. De Zootec. 2012, 61, 51-66. [CrossRef]

62. Piñeiro-Vázquez, A.T.; Canul-Solis, J.R.; Casanova-Lugo, F.; Chay-Canul, A.J.; Ayala-Burgos, A.; Solorio-Sánchez, J.; Aguilar-Pérez, C.F.; Ku-Vera, J.C. Emisión de metano en ovinos alimentados con Pennisetum purpureum y árboles que contienen taninos condensados. Rev. Mex. Cienc. Pecu. 2017, 2, 111-119. [CrossRef]

63. Bhatta, R.; Tajima, K.; Takusari, N.; Higuchi, K.; Enishi, O.; Kurihara, M. Comparison of in vivo and in vitro techniques for methane production from Ruminant diets. Asian-Aust. J. Anim. Sci. 2007, 20, 1049-1056. [CrossRef] 